\title{
Direct Effects of Catecholamines, Thyrotropin-releasing Hormone, and Somatostatin on Growth Hormone and Prolactin Secretion from Adenomatous and Nonadenomatous Human Pituitary Cells in Culture
}

\author{
Miyuki Ishibashi and Tohru Yamaji \\ Third Department of Internal Medicine, Faculty of Medicine, \\ University of Tokyo, Hongo, Tokyo 113, Japan
}

bstract. To determine the mechanism and the site of action of catecholamines as well as hormones including thyrotropin-releasing hormone (TRH) ${ }^{1}$ and somatostatin on pituitary hormone release in patients with acromegaly and in normal subjects, the effects of these substances on growth hormone (GH) and prolactin (PRL) secretion from adenomatous and nonadenomatous human pituitary cells in culture were examined. When dopamine $(0.01-0.1 \mu \mathrm{M})$ or bromocriptine $(0.01-0.1 \mu \mathrm{M})$ was added to the culture media, a significant inhibition of GH and PRL secretion from adenoma cells from acromegalic patients was observed. This inhibition was blocked by $\mathrm{D}_{2}$ receptor blockade with metoclopramide or sulpiride, but not by $\mathrm{D}_{1}$ receptor blockade. Similarly, dopamine suppressed GH and PRL release by nonadenomatous pituitary cells in a dose-dependent manner, which was again blocked by $\mathrm{D}_{2}$ receptor blockade. The minimum effective concentration of dopamine required for a significant inhibition of PRL secretion $(0.01 \mu \mathrm{M})$ was lower than that for $\mathrm{GH}$ release $(0.1 \mu \mathrm{M})$. Norepinephrine, likewise, caused a suppression of PRL secretion from adenomatous and nonadenomatous pituitary cells. This effect was blocked by sulpiride, phentolamine, however, was ineffective. When TRH was added to the media, both GH and PRL secretion were enhanced in adenoma cells, while only the stimulation of PRL release was observed in nonadenomatous pituitary cells. Coincubation of TRH and dopamine resulted in variable effects on $\mathrm{GH}$ and PRL secretion. Somatostatin consistently lowered

Received for publication 23 August 1982 and in revised form 2 September 1983.

J. Clin. Invest.

(c) The American Society for Clinical Investigation, Inc.

$0021-9738 / 84 / 01 / 0066 / 13 \quad \$ 1.00$

Volume 73, January 1984, 66-78
GH and PRL secretion in both adenomatous and nonadenomatous pituitary cells and completely blocked the TRH-induced stimulation of GH and PRL secretion from adenoma cells. Opioid peptides $(1 \mu \mathrm{M})$ failed to affect hormone release. These results suggest that no qualitative difference in GH and PRL responses to dopaminergic agonists or to somatostatin exists between adenoma cells of acromegalic patients and normal pituitary cells, and that the direct effect of catecholamines on GH and PRL secretion from human pituitary cells is mediated mainly through dopamine receptor activation.

\section{Introduction}

Anomalous or paradoxical responses of growth hormone $(\mathrm{GH})^{1}$ secretion to various stimuli in acromegalic patients have been well documented. Administration of dopaminergic agonists to normal men results in an elevation of the circulating levels of GH (1-4). In contrast, the same maneuver has been shown to decrease serum GH levels in most, though not all, patients with acromegaly $(3,5-8)$. On the basis of this finding, bromocriptine, a dopaminergic agonist with a prolonged action, has been successfully introduced into the medical management of this disorder (9-12).

We have previously shown, using an in vitro perfusion technique, that dopaminergic agonist does inhibit $\mathrm{GH}$ and prolactin (PRL) secretion from perfused pituitary adenoma tissues of acromegalic patients (13). This finding was subsequently confirmed by other investigators (14-18). We have also demonstrated by this experimental approach that thyrotropin-releasing hormone (TRH) acts on adenoma tissues from acromegalic patients to induce GH and PRL release (13), which is in good agreement with the observation that administration of TRH elevates serum levels of GH and PRL in many acromegalic patients $(19,20)$.

1. Abbreviations used in this paper: GH: growth hormone; L-dopa, 13,4-dihydroxyphenylalanine; hGH, human GH; PRL, prolactin; TRH, thyrotropin-releasing hormone. 
These results indicate that dopaminergic agonists and TRH affect GH and PRL secretion in these patients by their direct action on pituitary adenoma, and further suggest that a possible alteration in cellular membrane receptors of the pituitary adenoma of acromegalic patients may be responsible for anomalous $\mathrm{GH}$ responses. Of importance in this regard is the fact that the in vitro responses of normal human pituitaries to these stimuli are not well established. Moreover, a number of substances, in addition to dopaminergic agonists and TRH, has been shown to affect GH and PRL secretion in acromegalic subjects, which includes adrenergic $(21,22)$ and serotoninergic antagonists $(23$, 24). The present study was undertaken to examine the effects of these substances on GH and PRL secretion from pituitary adenoma cells of acromegaly at the cellular level using monolayer tissue culture, and to correlate them with the responses of nonadenomatous human pituitary cells in culture.

\section{Methods}

Subjects. 11 patients with acromegaly were studied. They consisted of seven men and four women aged between 24 and $56 \mathrm{yr}$. Their preoperative clinical data are summarized in Table I. They exhibited physical features of acromegaly, elevated base-line plasma GH concentrations, and failure of plasma GH levels to suppress during an oral glucose tolerance test. Intravenous injection of $0.5 \mathrm{mg}$ of synthetic TRH stimulated PRL release in all of the subjects and GH release in 10 of them (patients 1-3 and 5-11) shortly after the TRH administration. In seven patients studied (patients 1, 3-6, 10, and 11), administration of a single dose $(5 \mathrm{mg}$ orally) of bromocriptine (2-brom- $\alpha$-ergocriptine, CB 154; Sandoz Ltd., Basel, Switzerland) significantly suppressed their plasma GH and PRL levels; the nadir after bromocriptine administration reached 8.0-60.8\% of the base line for GH and $20.5-51.2 \%$ for PRL. The response to a given stimulus was judged to be positive when an elevation or a reduction in plasma GH and PRL concentrations exceeded twice the standard deviation from the mean value of the spontaneous fluctuation of plasma hormone levels examined in the control study without drug administration in each patient. Light microscopy of the pituitary adenomas removed from these patients at surgery revealed that five (No. 1, 3, 6, 8 , and 9) of them were eosinophilic, while the remaining six were chromophobic.

Nonadenomatous anterior pituitary tissues were obtained from a subject with metastatic breast cancer (N1), who received neither adrenocortical hormones nor other steroidal regimen and three patients with Cushing's disease (N2-N4) at the time of hypophysectomy.

Monolayer culture of pituitary tissues. Pituitary tissues obtained at surgery were cultured in monolayer. The method for the monolayer culture of pituitary cells has been previously described in detail (25). Pituitary adenomas or nonadenomatous pituitary tissues were cut into small pieces and dispersed by incubation with $10 \mathrm{ml}$ of trypsin-collagenase solution at $37^{\circ} \mathrm{C}$ with gentle magnetic stirring. The solution contained $0.25 \mathrm{~g}$ trypsin (Difco Laboratories, Detroit, MI), $20 \mathrm{mg}$ collagenase (type IV; Worthington Biochemical Corp., Freehold, NJ), and $0.05 \mathrm{~g}$ glucose

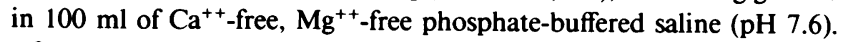
After $10 \mathrm{~min}$ of incubation, the supernatant suspension containing dissociated cells was removed, diluted with cold culture medium and kept on ice until the final centrifugation. To the remaining tissue fragments was then added another $10 \mathrm{ml}$ of trypsin-collagenase solution and the digestion procedure was repeated two to three times until cells were
Table I. Laboratory Findings in the 11 Acromegalic Subjects Studied

\begin{tabular}{|c|c|c|c|c|c|c|c|c|}
\hline \multirow{2}{*}{$\begin{array}{l}\text { Case } \\
\text { no. }\end{array}$} & \multirow[b]{2}{*}{ Age } & \multirow[b]{2}{*}{ Sex } & \multicolumn{2}{|c|}{ Basal level } & \multicolumn{2}{|c|}{$\begin{array}{l}\text { Response to } \\
\text { TRH* }^{*}\end{array}$} & \multicolumn{2}{|c|}{$\begin{array}{c}\text { Response to } \\
\text { bromocriptine }\end{array}$} \\
\hline & & & $\mathrm{GH}$ & PRL & $\mathrm{GH}$ & PRL & $\mathrm{GH}$ & PRL \\
\hline & $y r$ & & $n g / m l$ & $n g / m l$ & $\%$ & $\%$ & $\%$ & $\%$ \\
\hline 1 & 33 & $\mathbf{M}$ & 68 & 9 & 456 & 433 & 8.0 & 38.5 \\
\hline 2 & 29 & $F$ & 40 & 5 & 146 & 315 & - & - \\
\hline 3 & 48 & $\mathbf{M}$ & 144 & 12 & 1,444 & 174 & 19.9 & 20.5 \\
\hline 4 & 48 & $\mathbf{M}$ & 171 & 7 & 119 & 143 & 60.8 & 30.3 \\
\hline 5 & 24 & $\mathbf{M}$ & 57 & 36 & 1,096 & 261 & 32.9 & 23.6 \\
\hline 6 & 56 & $\mathrm{~F}$ & 41 & 8 & 204 & 481 & 25.2 & 27.9 \\
\hline 7 & 29 & $F$ & 143 & 19 & 1,014 & 156 & - & - \\
\hline 8 & 38 & $\mathbf{M}$ & 40 & 8 & 375 & 240 & - & - \\
\hline 9 & 46 & $\mathbf{M}$ & 24 & 13 & 637 & 260 & - & - \\
\hline 10 & 35 & $\mathbf{M}$ & 34 & 9 & 250 & 292 & 23.7 & 22.0 \\
\hline 11 & 46 & $F$ & 97 & 28 & 289 & 143 & 56.8 & 51.2 \\
\hline
\end{tabular}

* TRH $(0.5 \mathrm{mg})$ was injected intravenously and blood samples were collected at $0,15,30,60,90$, and 120 min after the injection. Peak GH and PRL concentrations were expressed in terms of a percentage of the control levels.

¥ Bromocriptine ( $5 \mathrm{mg}$ ) was administered orally and blood samples were collected at 30-min intervals for $4 \mathrm{~h}$. The lowest GH and PRL concentrations observed after the bromocriptine administration were expressed in terms of a percentage of the control levels.

completely dispersed. The supernatant fluids were pooled followed by centrifugation at $150 \mathrm{~g}$ for $10 \mathrm{~min}$. Cells were washed with cold culture medium and resuspended in an appropriate volume (usually $60 \mathrm{ml}$ ) of culture medium, which consisted of Eagle's minimum essential medium in Earle's solution including $10 \%$ fetal calf serum, $100 \mathrm{U} / \mathrm{ml}$ penicillin, and $100 \mu \mathrm{g} / \mathrm{ml}$ streptomycin sulfate. A $2-\mathrm{ml}$ aliquot containing 2-8 $\times 10^{5}$ dissociated cells was planted in each plastic petri dish $(35 \times 100$ $\mathrm{mm}$, Corning Glass Works, Corning Medical and Scientific, Corning, $\mathrm{NY}$ ) and incubated at $37^{\circ} \mathrm{C}$ in a humidified atmosphere of $95 \%$ air and $5 \% \mathrm{CO}_{2}$. Viability of the cells at plating determined by trypan blue exclusion was always $>95 \%$.

GH biosynthesis experiment. To validate the monolayer culture system utilized in the present study, biosynthesis of $\mathrm{GH}$ in pituitary adenoma cells from patient 11 was studied. On 19th $d$ of culture, the medium was replaced by $2 \mathrm{ml}$ of leucine-free medium supplemented with $10 \mu \mathrm{Ci} /$ dish of $\mathrm{L}-\left[{ }^{3} \mathrm{H}\right]$ leucine $(136 \mathrm{Ci} / \mathrm{mmol}$, Amersham Corp., Amersham, England). Cells were incubated at $37^{\circ} \mathrm{C}$ for varying periods of time under the atmosphere of $95 \%$ air and $5 \% \mathrm{CO}_{2}$. At the end of the incubation, the medium was removed and the cells were washed with $0.9 \%$ saline followed by extraction.

Extraction and immunoprecipitation of $\mathrm{GH}$ were conducted according to the general method described by Mains and Eipper (26) for adrenocorticotropic hormone with a modification (27). Cells were frozen and thawed several times on dry ice and homogenized in $0.6 \mathrm{ml}$ of 0.01 $\mathrm{N} \mathrm{NaOH} \mathrm{(28)} \mathrm{with} \mathrm{a} \mathrm{Teflon} \mathrm{pestle.} \mathrm{Extracts} \mathrm{were} \mathrm{titrated} \mathrm{to} \mathrm{pH} 7.5$ with $1 \mathrm{~N} \mathrm{HCl}$ and centrifuged at $2,300 \mathrm{~g}$ for $15 \mathrm{~min}$ at $4^{\circ} \mathrm{C}$. An aliquot $(10 \mu \mathrm{l})$ of the supernate was incubated at $4^{\circ} \mathrm{C}$ with a sufficient amount $(0.5 \mu \mathrm{l})$ of a specific rabbit anti-human (h)GH serum or nonimmune 
rabbit serum in the presence of $40 \mu \mathrm{l}$ of $0.5 \%$ bovine serum albumin/ $0.1 \mathrm{M}$ borate buffer ( $\mathrm{pH} 8.6$ ). This antiserum was generously provided by Dr. H. Demura of Tokyo Womens' Medical College. After $24 \mathrm{~h}$ of incubation, anti-rabbit IgG was added in an amount that maximally precipitated the rabbit IgG and incubation was continued overnight. Tubes were then centrifuged, and the immunoprecipitates of cell extracts were washed once in $2 \mathrm{ml}$ of $0.05 \mathrm{M}$ phosphate buffer containing $5 \mathrm{mM}$ $\mathrm{Na}_{2}$ EDTA and $0.25 \%$ Triton X-100 (pH 7.6) and once in $2 \mathrm{ml}$ of 0.01 $\mathrm{M}$ phosphate buffer containing $15 \mathrm{mM} \mathrm{NaCl}(\mathrm{pH} \mathrm{7.2)}$. The immune complex was dissolved by incubation in $0.2 \mathrm{ml}$ of NCS tissue solubilizer (Amersham Corp., Arlington Heights, IL) and counted in a liquid scintillation spectrometer with $10 \mathrm{ml}$ of scintillation fluid containing $6 \mathrm{~g}$ PPO and $0.1 \mathrm{~g}$ POPOP/liter of toluene.

Incubation of cells with test substances. Incubation studies were started after the cells formed a monolayer and performed at an interval of at least $2 \mathrm{~d}$. Individual cultures were randomly allocated for each experiment. Four or more cultures were used for the control and variables, and run simultaneously.

On the day of experiment, the medium was replaced by $2 \mathrm{ml}$ of Eagle's minimum essential medium in Earle's solution containing $0.5 \%$ human serum albumin instead of fetal calf serum. Cells were incubated for $1 \mathrm{~h}$ at $37^{\circ} \mathrm{C}$ in a humidified atmosphere of $95 \%$ air and $5 \% \mathrm{CO}_{2}$. The medium was then removed and cells were further incubated for 2 $\mathrm{h}$ in $2 \mathrm{ml}$ of fresh medium with or without the following substances: dopamine hydrochloride, L-3,4-dihydroxyphenylalanine (L-dopa), bromocriptine mesylate, haloperidol, metoclopramide, sulpiride, pimozide, YM-09151-2 (Yamanouchi Pharmaceutical Co., Tokyo, Japan) (29), norepinephrine, phentolamine mesylate, TRH, somatostatin (Protein Research Foundation, Osaka, Japan), $\alpha$-endorphin (Peninsula Laboratories, Inc., Belmont, CA), $\beta$-endorphin (Peninsula Laboratories, Inc.), and methionine enkephalin (Calbiochem-Behring Corp., American Hoechtst Corp., San Diego, CA) In general, fresh solutions of these substances were prepared before each experiment by dissolving them directly in the incubation medium, with a few exceptions. Bromocriptine mesylate and haloperidol were first solubilized in glacial acetic acid and then diluted to a concentration of $10 \mathrm{mg} / \mathrm{ml}$ with distilled water. These stock solutions were serially diluted to an appropriate concentration with $0.9 \%$ saline and then with the incubation medium. YM-09151-2 was initially dissolved in $0.01 \mathrm{~N} \mathrm{HCl}$ at a concentration of $1 \mathrm{mg} / \mathrm{ml}$ followed by dilution with $0.9 \%$ saline and the incubation medium. Dopamine, norepinephrine, and L-dopa were dissolved immediately before the experiment in the incubation medium, which contained ascorbic acid at the final concentration of $0.1 \mathrm{mM}$. Control dishes received vehicle alone. When the combined effect of two test substances on hormone release was examined, they were added simultaneously to the incubation media. After incubation, the medium was centrifuged at $150 \mathrm{~g}$ for 10 min, and the supernate was stored at $-20^{\circ} \mathrm{C}$ until analyzed.

Radioimmunoassays. GH and PRL concentrations in the medium of both preincubation and experimental incubation were determined by radioimmunoassays, as previously described in detail $(7,30)$. Immunological materials for the radioimmunoassays were kindly donated by the National Institute of Arthritis, Metabolism, and Digestive Diseases and the National Pituitary Agency, U. S. Public Health Service. Crossreactivity of GH in PRL radioimmunoassay was $0.13 \%$ and that of PRL in GH radioimmunoassay was $0.73 \%$. The coefficients of variation for GH averaged $5.3 \%$ for intraassay error and $9.6 \%$ for interassay error, while they were estimated to be 7.4 and $8.2 \%$, respectively, for PRL. Results are expressed as the percentage of hormone secreted in the experimental incubation, compared with that secreted during the preincubation for individual cultures. For comparison, the mean values obtained in the control study were designated as $100 \%$.

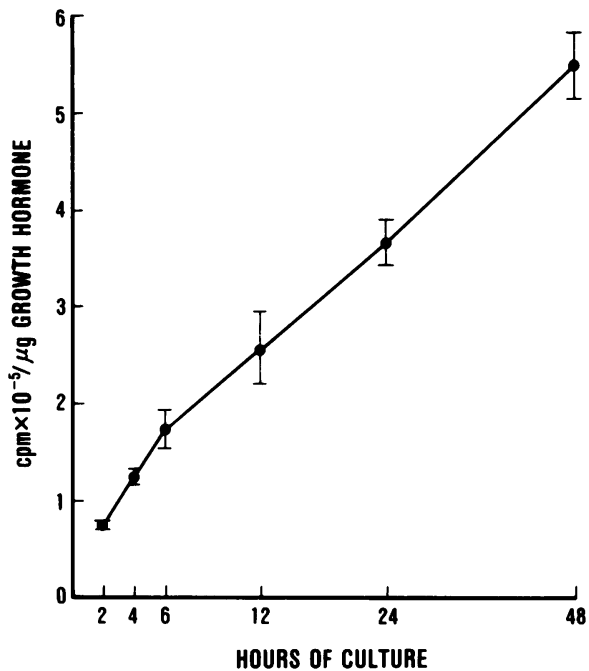

Figure 1. Incorporation of $\left[{ }^{3} \mathrm{H}\right]$ leucine into immunoprecipitable $\mathrm{GH}$ in cell extracts. Cultured cells obtained from a patient with acromegaly (patient 11 ) were incubated with leucine-free medium supplemented with $\mathrm{L}-\left[{ }^{3} \mathrm{H}\right]$ leucine for varying periods of time. No significant radioactivity was observed in the immunoprecipitate when anti-hGH serum was replaced by nonimmune rabbit serum. Each group consists of four dishes. Results are the mean \pm SEM.

Statistical analysis. Values in figure and text are given as the mean \pm SEM unless otherwise specified. The significance of differences was calculated using Student's $t$ test and analysis of variance.

\section{Results}

GH biosynthesis in cultured pituitary adenoma cells. Dispersed cells of pituitary adenomas from acromegalic patients formed a monolayer attaching to the culture dishes within the first 48$72 \mathrm{~h}$. The plating efficiencies of cells ranged from 20 to $39 \%$ (mean 29\%).

To observe the kinetics of labeling of GH in cultured pituitary adenoma cells from acromegalic patients, cells were incubated with labeled leucine and harvested after increasing periods of time from 2 to $48 \mathrm{~h}$. Incorporation of $\left[{ }^{3} \mathrm{H}\right]$ leucine into immunoprecipitable $\mathrm{GH}$ in cell extracts proceeded linearly for the entire 48-h incubation (Fig. 1), while no significant radioactivity was observed in the immunoprecipitates when anti-hGH was replaced by nonimmune rabbit serum. The result suggests that de novo hormone synthesis is actively taking place in pituitary cells in monolayer culture under the present experimental conditions.

GH and PRL secretion from cultured pituitary cells. Fig. $2 A$ shows the hourly secretion rates of $\mathrm{GH}$ by adenoma cells of acromegaly on different culture days. Secretion of GH was well maintained throughout the period of observation by changing culture medium at 2-4-d intervals, although a gradual decrease in GH release was seen when the culture was continued. In all of the adenoma cells with a single exception (No. 3), the concomitant secretion of PRL was observed (Fig. 2 B). The 

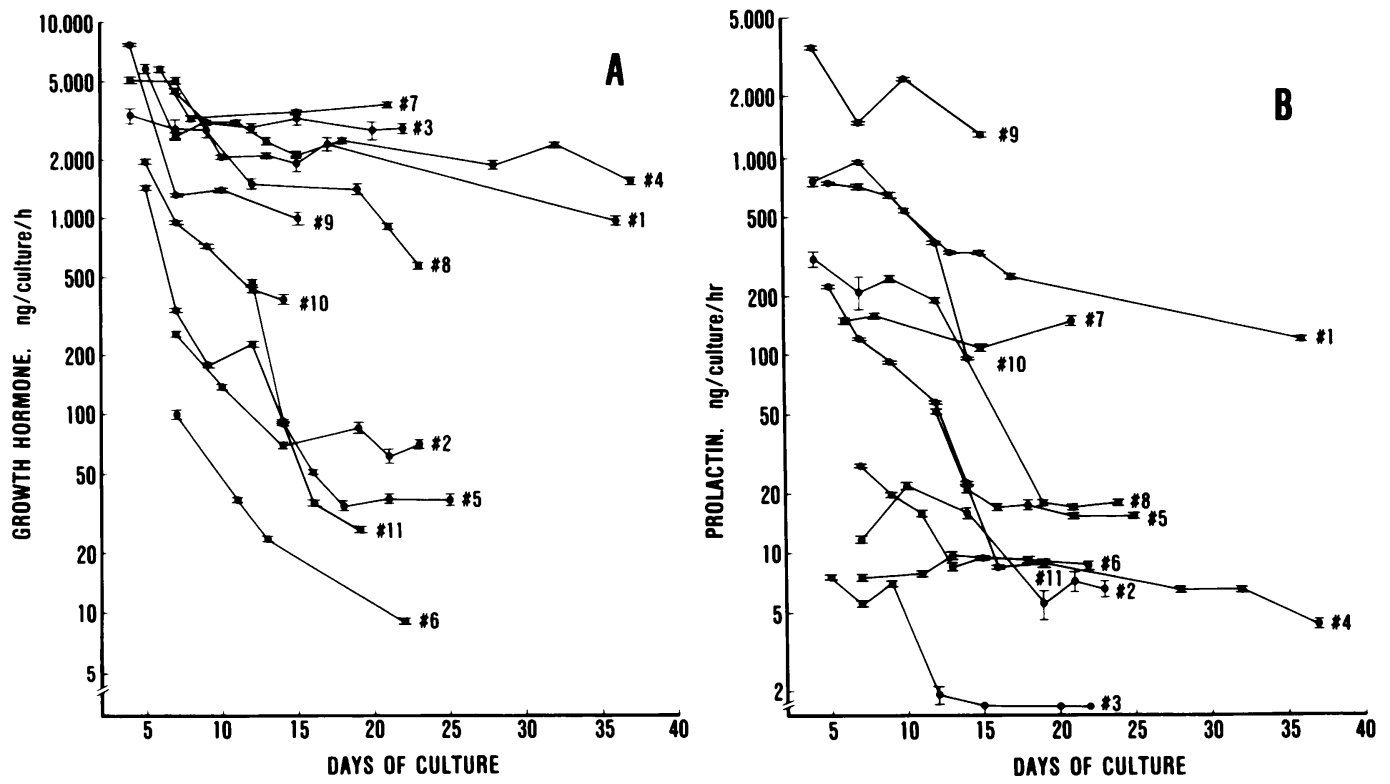

Figure 2. Hourly secretion rates of $\mathrm{GH}(A)$ and PRL $(B)$ on different days of culture from pituitary adenoma cells of the 11 patients with acromegaly. Cells were incubated with fresh medium (minimum essential medium in Earle's solution) containing $0.5 \%$ human serum albumin for $1 \mathrm{~h}$. Each group consists of 18-30 culture dishes. Results are the mean \pm SEM.

secretion rates of PRL varied from tissue to tissue and were quantitatively less when compared with those of $\mathrm{GH}$, being 15.8 (No. 1), 4.8 (No. 2), 0.63 (No. 4), 10.9 (No. 5), 7.6 (No. 6), 2.6 (No. 7), 8.1 (No. 8), 47.6 (No. 9), 32.8 (No. 10), and 15.9\% (No. 11) of GH secretion rates at the initial incubation study, respectively. That adenoma tissue was contaminated with adjacent normal pituitary lactotrophs seemed unlikely, since the tissue was obtained at transsphenoidal selective removal of adenomas and histologic examination performed in randomly selected tissue pieces revealed that all of them possessed characteristics of eosinophilic or chromophobe adenoma. In view of the degree of the cross-reaction of GH in PRL radioimmunoassay, PRL secretion by adenoma cells obtained from patient 3 was judged to be only minimal.

Similarly, nonadenomatous human pituitary cells in culture actively secreted both GH and PRL. The amounts of GH accumulated in the media at the initial incubation study were $83.7 \pm 5.0($ mean \pm SEM,$n=30)(\mathrm{N} 1), 151.1 \pm 5.0(n=25)(\mathrm{N} 2)$,
$12.1 \pm 0.5(n=16)(\mathrm{N} 3)$, and $4.3 \pm 0.3 \mathrm{ng} / \mathrm{h}$ per dish $(n=30)$ (N4), respectively. The secretion rates of PRL, on the other hand, were $201.3 \pm 11.1(\mathrm{~N} 1), 90.1 \pm 3.1(\mathrm{~N} 2), 8.3 \pm 0.4(\mathrm{~N} 3)$, and $74.2 \pm 2.8 \mathrm{ng} / \mathrm{h}$ per dish (N4), respectively.

Effect of dopamine and dopaminergic agonists on $\mathrm{GH}$ and $P R L$ secretion from cultured pituitary cells. The effect of varying doses of dopamine on GH and PRL secretion from different nonadenomatous pituitary cells is shown in Fig. 3. In all of the experiments, both GH and PRL secretion were inhibited by dopamine and, in addition, a dose-response relationship was observed between the dopamine concentrations and the amounts of hormones secreted into the media. The minimum effective concentration of dopamine required for a significant inhibition of PRL release $(0.01 \mu \mathrm{M})$ was lower than that for $\mathrm{GH}$ secretion $(0.1 \mu \mathrm{M})$.

When dopamine at a concentration of 0.01 or $0.1 \mu \mathrm{M}$ was added to the incubation media, both GH and PRL release were significantly suppressed in adenoma cells of acromegaly. This

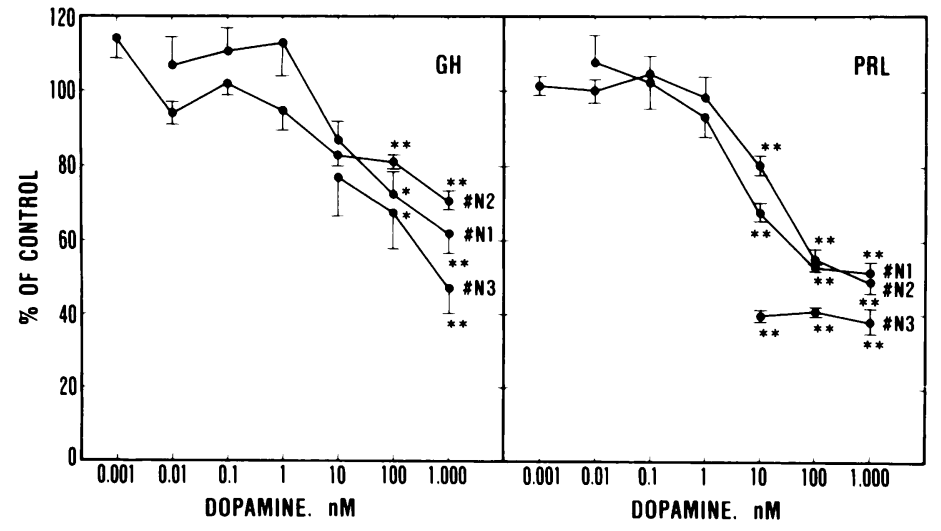

Figure 3. Effect of varying doses of dopamine on GH and PRL secretion by cultured nonadenomatous human pituitary cells obtained from a subject with metastatic breast cancer (patient $\mathrm{N} 1$ ) and two patients with Cushing's disease (patients $\mathrm{N} 2$ and N3) at the time of hypophysectomy. A minimum of four replicates was used for each variable. Results are expressed as the percentage of change in secretion relative to a preincubation in medium alone. For comparison, the mean values for control incubation were designated as $100 \%$. Results are the mean \pm SEM. ${ }^{*} P<0.05$ vs. control; ${ }^{* *} P<0.01$ vs. control. 


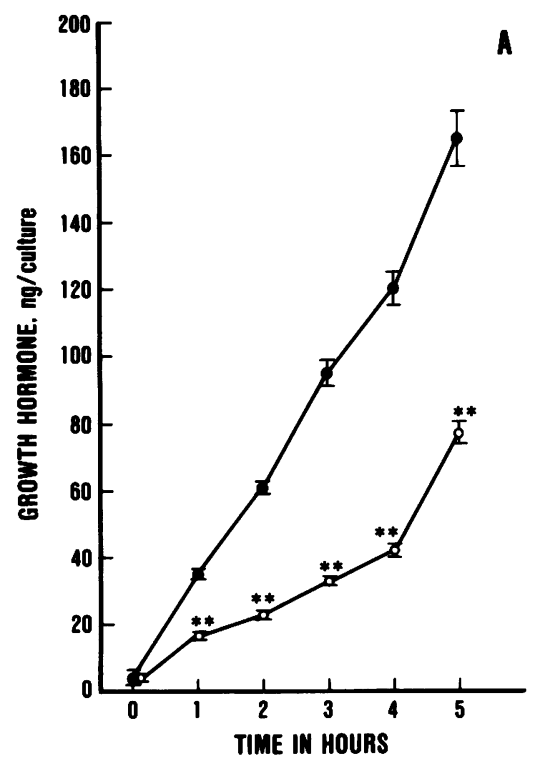

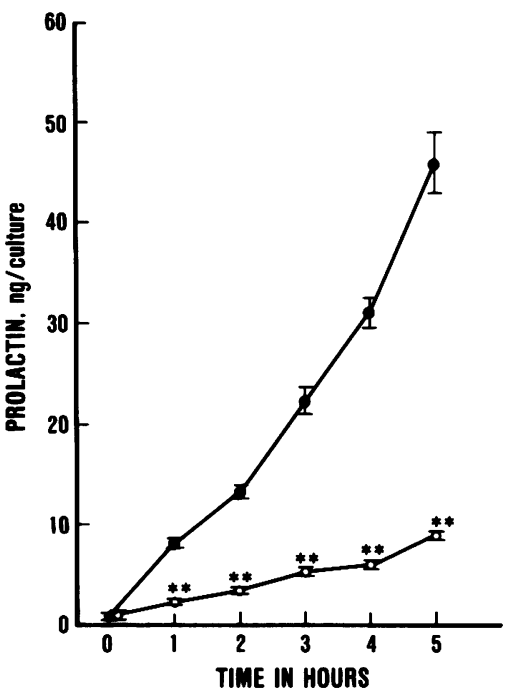

Figure 4. Time course of the inhibitory effect of dopamine on GH $(A)$ and PRL $(B)$ secretion by cultured adenoma cells obtained from a patient with acromegaly (patient 11 ). Cells were incubated with (open circles) or without (filled circles) $0.1 \mu \mathrm{M} \mathrm{DA}$ and aliquots $(0.1 \mathrm{ml})$ of the incubation media were taken every $1 \mathrm{~h}$ during $5 \mathrm{~h}$ of incubation. Each group consists of 10 dishes. Results are the mean \pm SEM. $* * P<0.01$. inhibitory effect of dopamine on GH and PRL secretion was unequivocally demonstrated in cells taken from 11 different tumors of acromegalic patients. In one experiment, adenoma cells (No. 11) were incubated with $0.1 \mu \mathrm{M}$ of dopamine and aliquots $(0.1 \mathrm{ml})$ of the incubation media were collected every hour. As shown in Fig. 4, the accumulation of GH and PRL in the incubation medium increased in a linear fashion in the control, while a significant decrease in both $\mathrm{GH}$ and PRL release by dopamine was observed over the 5 -h period, indicating that dopamine is fairly stable in the incubation medium, or alternatively, the inhibitory effect of dopamine on GH and PRL release lasts for at least $5 \mathrm{~h}$.

When haloperidol, a nonselective dopaminergic antagonist (31), was coincubated, the effect of dopamine on GH and PRL secretion was blocked in all of the six adenoma cells examined (No. 2, 3, and 8-11, Fig. 5). The addition of metoclopramide or sulpiride, selective $D_{2}$ dopamine receptor antagonists (31), also blocked the inhibitory action of dopamine on $\mathrm{GH}$ release in four experiments (Fig. 5), although it did not completely abolish the suppressive effect of dopamine on PRL release in three different adenoma cells (No. 4, 8, and 9, Fig. 5). A selective $D_{1}$ dopamine receptor antagonist, YM-09151-2 (29), on the other hand, failed to overcome the inhibitory effect of dopamine on both GH and PRL secretion in four different adenoma cells studied (No. 8-11, Fig. 5).

In an attempt to determine whether L-dopa, which is known to lower serum GH levels of some acromegalic patients (5), may act on pituitary adenomas to affect $\mathrm{GH}$ secretion, the direct effect of L-dopa was studied using three different adenoma cells of acromegaly in culture. L-Dopa at a concentration of $0.1 \mu \mathrm{M}$ showed little effect, although the equimolar concentration of dopamine significantly inhibited both GH and PRL secretion in all of the experiments (Figs. 4 and 5). In one experiment,
PRL secretion showed a slight but a significant reduction in response to this dose of $L$-dopa.

The effect of dopamine on GH and PRL secretion from nonadenomatous pituitary cells is shown in Fig. 6 . The addition of $0.1 \mu \mathrm{M}$ dopamine to the culture media induced a significant inhibition of $\mathrm{GH}$ release in all of the three experiments conducted on different nonadenomatous somatotrophs. This inhibitory effect of dopamine on GH secretion observed in nonadenomatous GH cells was abolished by coincubation with an equimolar concentration of haloperidol. Similarly, sulpiride competed with the inhibitory action of dopamine on GH release (N2, Fig. 6), while YM-09151-2, a $D_{1}$ receptor antagonist did not. The inhibitory effect of dopamine on PRL secretion from nonadenomatous lactotrophs was more pronounced than that on GH release. This action of dopamine was again blocked by the addition of haloperidol or sulpiride. $A D_{1}$ receptor blockade with YM-09151-2 was inert in this regard.

Bromocriptine, likewise, significantly suppressed GH and PRL secretion from five adenomatous and one nonadenomatous pituitary cells at a concentration of 0.01 or $0.1 \mu \mathrm{M}$. The addition of haloperidol or pimozide blocked this inhibitory effect of bromocriptine. The concentration of haloperidol required for the reversal of the inhibitory effect by bromocriptine was larger (10-100-fold concentrations of bromocriptine) than in the case of dopamine.

Effect of norepinephrine on $G H$ and PRL secretion from cultured pituitary cells. In Fig. 7 is shown the effect of norepinephrine on GH and PRL release by pituitary adenoma cells from acromegalic patients. Norepinephrine at a concentration of $0.01 \mu \mathrm{M}$ did not produce any significant effect, however, the addition of $0.1 \mu \mathrm{M}$ norepinephrine equally resulted in a significant decrease in PRL secretion in experiments using adenoma cells from five different acromegalic patients. This effect of nor- 

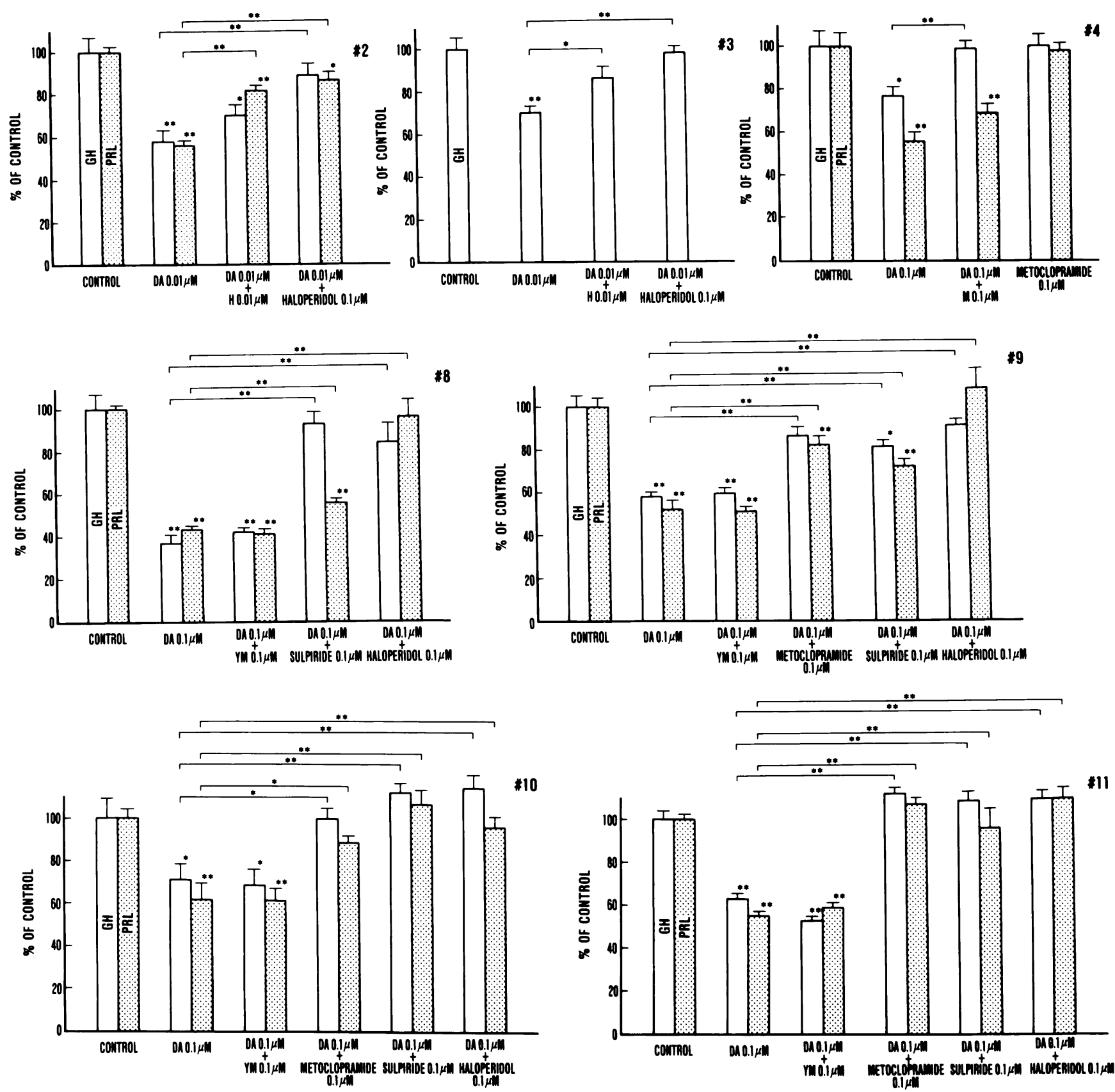

Figure 5. Effect of dopamine (DA) alone or in combination with dopaminergic antagonists (haloperidol, metoclopramide, sulpiride, and YM-09151-2) on GH and PRL secretion by cultured adenoma cells obtained from patients with acromegaly (patients $2-4$ and 811). Open histograms represent GH and shaded histograms PRL. A

epinephrine on PRL secretion was blocked by the addition of an equimolar concentration of sulpiride in all of the four adenoma cells studied (No. 8-11, Fig. 7), while phentolamine was ineffective. The effect of norepinephrine on GH secretion from

minimum of four replicates was used for each variable. Results are expressed as the percentage of change in secretion relative to a preincubation in medium alone. For comparison, the mean values in the control incubation were designated as $100 \%$. Results are the mean \pm SEM. ${ }^{*} P<0.05 ;{ }^{* *} P<0.01$.

adenoma cells of acromegalic patients, on the other hand, was variable. In two experiments, norepinephrine at a concentration of $1 \mu \mathrm{M}$ induced a significant decrease in $\mathrm{GH}$ secretion, which was blocked by coincubation with an equimolar sulpiride (No. 

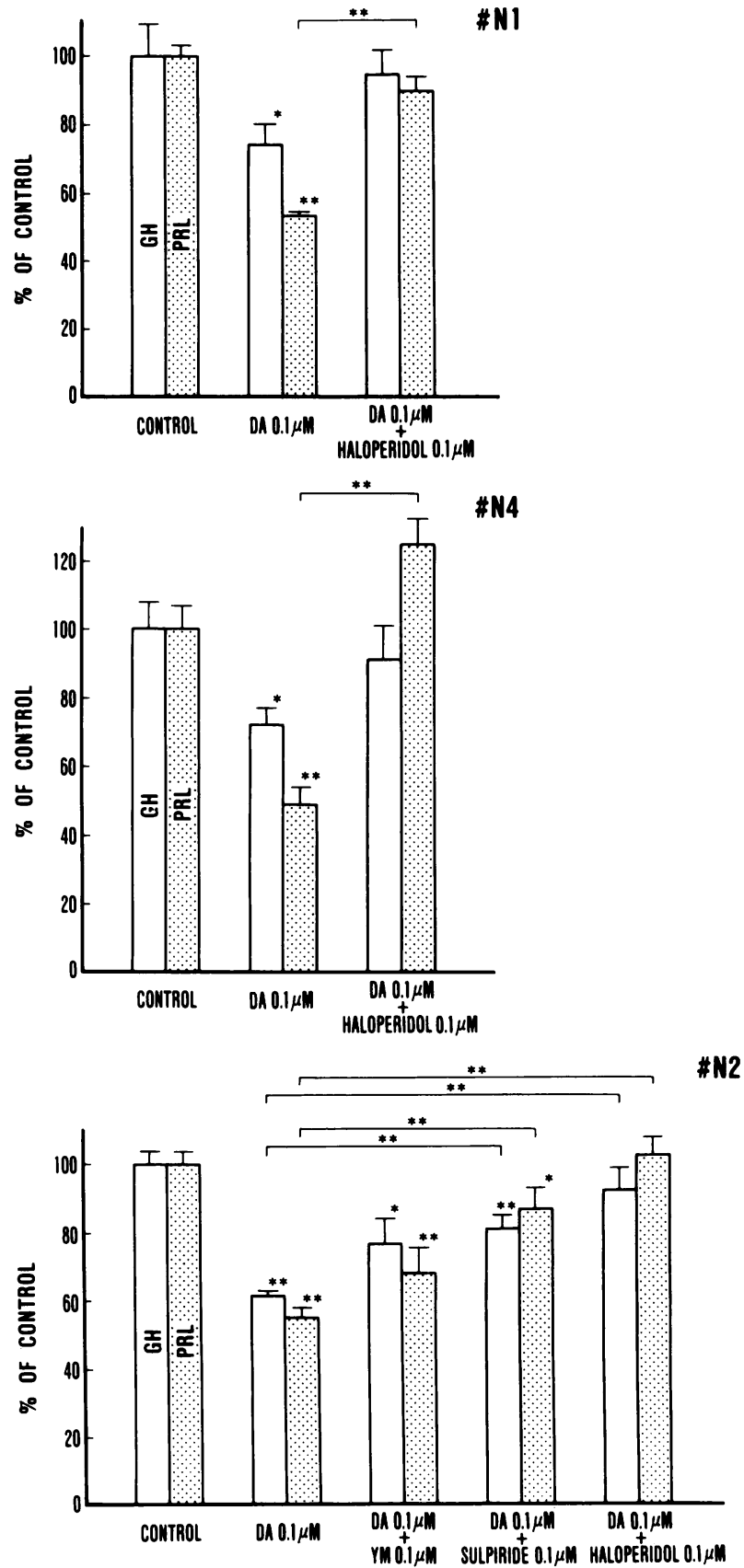

Figure 6. Effect of dopamine (DA) alone or in combination with dopaminergic antagonists (haloperidol, sulpiride, and YM-09151-2) on GH and PRL secretion by cultured nonadenomatous human pituitary cells obtained from a subject with metastatic breast cancer (patient N1) and two patients with Cushing's disease (patients N2 and N4) at the time of hypophysectomy. Open histograms represent GH and shaded histograms PRL. A minimum of four replicates was used for each variable. Results are expressed as the percentage of change in secretion relative to a preincubation in medium alone. For comparison, the mean values in the control incubation were designated as $100 \%$. Results are the mean \pm SEM. ${ }^{*} P<0.05$; ${ }^{* *} P<0.01$
10 and 11, Fig. 7). Phentolamine did not show any effect also in this occasion. In the remaining three experiments, no significant effect of norepinephrine $(0.1$ or $1 \mu \mathrm{M})$ on $\mathrm{GH}$ secretion by adenoma cells of acromegaly was observed.

Similarly, as in adenoma cells, norepinephrine at a concentration of $0.1 \mu \mathrm{M}$ consistently suppressed PRL secretion from nonadenomatous human pituitary cells in culture in two experiments. This inhibitory action of norepinephrine was blocked, though partially, by the addition of an equimolar concentration of sulpiride, phentolamine, however, failed to block the norepinephrine-induced inhibition of PRL release. GH secretion from nonadenomatous pituitary cells was significantly inhibited by norepinephrine $(0.1 \mu \mathrm{M})$ in one experiment. The addition of sulpiride blocked this effect, while phentolamine at an equimolar concentration did not compete with norepinephrine. In another experiment, the mean secretion rate of $\mathrm{GH}$ was attenuated in response to norepinephrine $(0.1 \mu \mathrm{M})$, but this difference was not statistically significant.

Effect of TRH on GH and PRL secretion from cultured pituitary cells. The addition of TRH to the incubation media significantly stimulated both GH and PRL secretion from cultured adenoma cells of acromegalic patients (Fig. 8). Furthermore, a dose-response relationship was obtained between the concentrations of TRH added and the amounts of hormones secreted into the media. This stimulatory effect of TRH on GH secretion was most clearly demonstrated in the adenoma cells of acromegaly obtained from patient 3 , in whom TRH induced a marked elevation of plasma GH levels (Table I). Similarly, TRH at a concentration of $0.1 \mu \mathrm{M}$ significantly stimulated PRL secretion from nonadenomatous pituitary cells in culture (N4, Fig. 8). TRH failed to enhance GH release from nonadenomatous somatotrophs in this experiment.

To study the interaction between the stimulatory effect of TRH and the inhibitory effect of dopaminergic agents, cultured adenoma cells from acromegalic patients were coincubated with TRH and dopamine. As shown in Fig. 9, dopamine at a concentration of 0.1 or $0.01 \mu \mathrm{M}$ significantly suppressed both $\mathrm{GH}$ and PRL release, whereas the addition of 0.1 or $0.01 \mu \mathrm{M}$ TRH to the incubation media resulted in a significant increase in $\mathrm{GH}$ and PRL secretion. When cells were incubated with dopamine in the presence of an equimolar concentration of TRH, the inhibitory effect of dopamine was overcome in two experiments (No. 3 and 6, Fig. 9). In the remaining one experiment, the effect of dopamine was not reversed by the addition of an equimolar concentration of TRH (No. 1, Fig. 9). When cells were incubated with bromocriptine instead of dopamine in three experiments, the doses of TRH required for the reversal of the inhibitory effect of bromocriptine were different from tissue to tissue and, in general, a higher dose of TRH was necessary.

Effect of somatostatin on $G H$ and PRL secretion from cultured pituitary cells. Fig. 10 illustrates the effect of somatostatin on GH and PRL secretion from adenoma cells of acromegalic patients and from nonadenomatous pituitary cells in culture. Somatostatin at a concentration of $0.1 \mu \mathrm{M}$ significantly sup- 

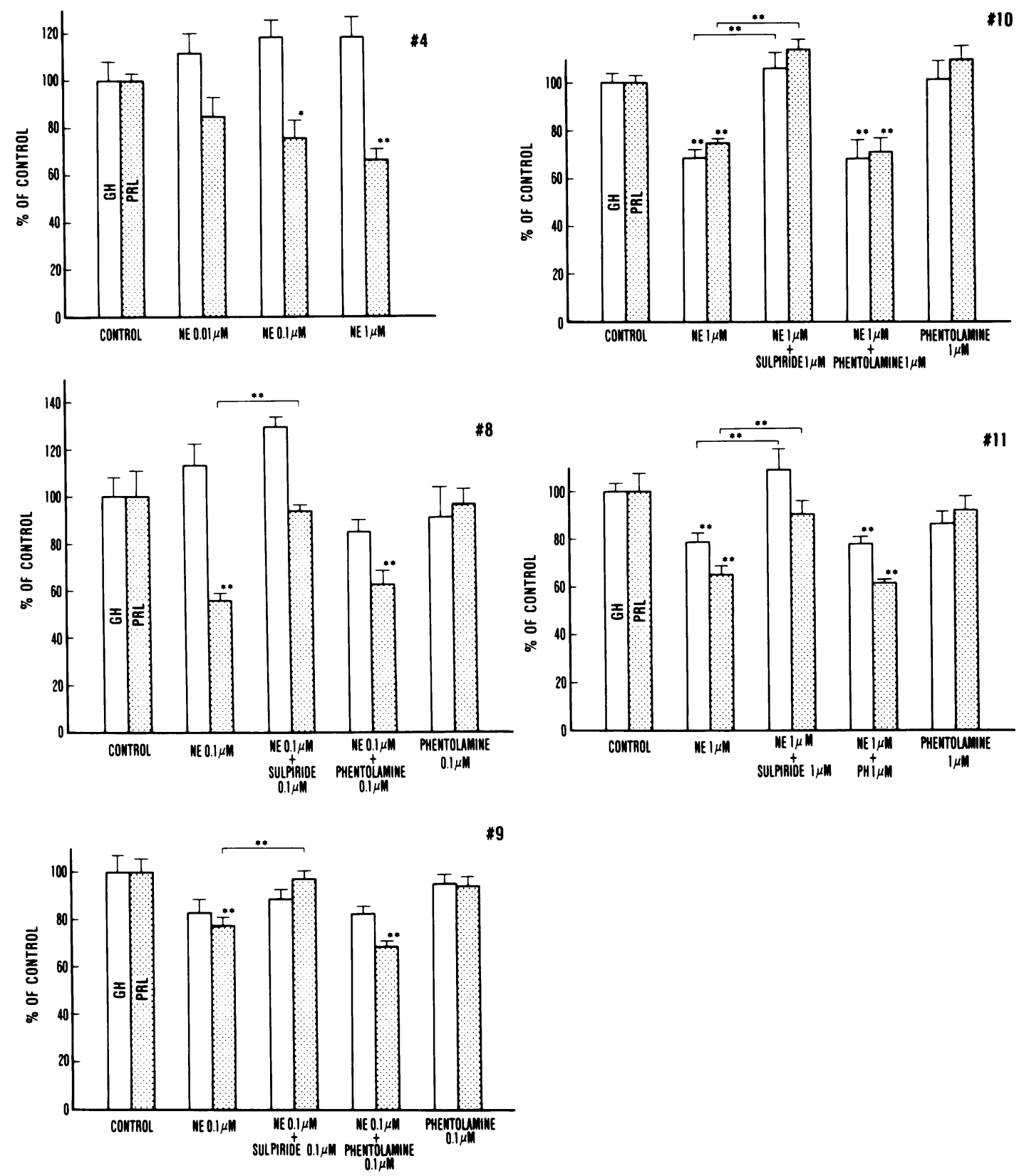

Figure 7. Effect of norepinephrine (NE) alone or in combination with phentolamine (PH) or sulpiride on GH and PRL secretion by cultured adenoma cells obtained from patients with acromegaly (patients 4 and 8-11). Open histograms represent GH and shaded histograms PRL. A minimum of four replicates was used for each

variable. Results are expressed as the percentage of change in secretion relative to a preincubation in medium alone. For comparison, the mean values for control incubation were designated as $100 \%$. Results are the mean \pm SEM. ${ }^{*} P<0.05 ;{ }^{* *} P<0.01$.

which was in good agreement with the in vivo GH response to TRH in this patient (Table I). Further increase in TRH concentration $(1 \mu \mathrm{M})$ did not reverse the inhibitory effect of somatostatin on both GH and PRL (No. 1, Fig. 10).

Moreover, in nonadenomatous pituitary cells, somatostatin pressed both GH and PRL release by adenoma cells in culture. The stimulatory effect of TRH on PRL secretion was completely blocked by coincubation with somatostatin at an equimolar concentration (No. 4, Fig. 10), although GH release was not enhanced in response to TRH in the adenoma cells studied, 

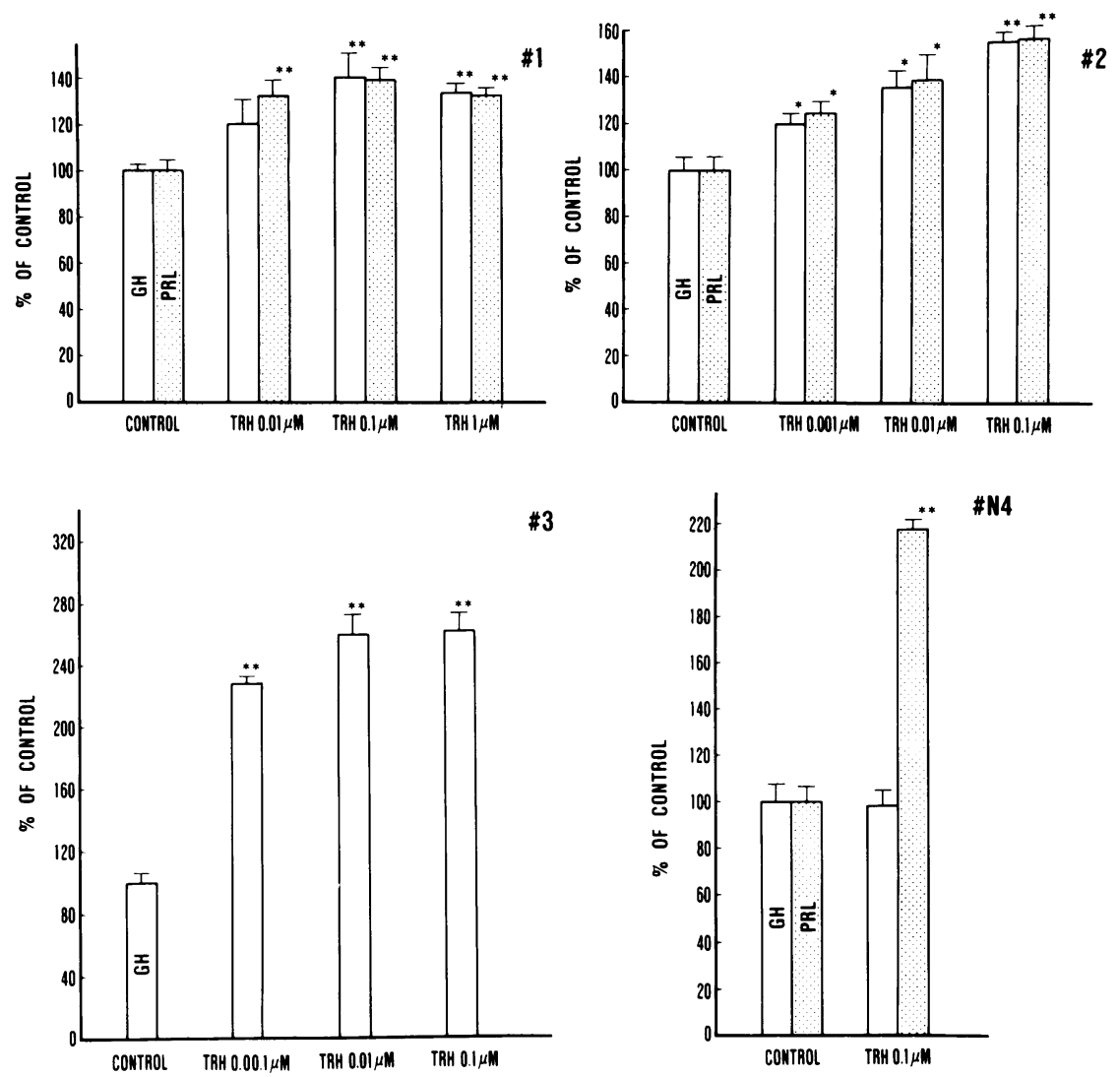

Figure 8. Effect of TRH on GH and PRL secretion by cultured adenoma cells obtained from patients with acromegaly (patients $1-3$ ) and by nonadenomatous human pituitary cells obtained from a patient with Cushing's disease (patient N4). Open histograms represent GH and shaded histograms PRL. A minimum of four replicates was used for each variable. Results are expressed as the percentage of change in secretion relative to a preincubation in medium alone. For comparison, the mean values in the control incubation were designated as $100 \%$. Results are the mean \pm SEM. ${ }^{*} P<0.05 ;{ }^{* *} P<0.01$.

at a concentration of $0.1 \mu \mathrm{M}$ exerted an inhibitory action on both GH and PRL secretion (N2, Fig. 10). The magnitude of suppression by somatostatin was more pronounced in $\mathrm{GH}$ secretion than in PRL release, contrary to the inhibitory effect of dopamine on hormone secretion.

Effect of opioid peptides on GH and PRL secretion from cultured pituitary cells. The addition of $\alpha$-endorphin, $\beta$-endorphin, or met-enkephalin alone at various concentrations up to $1 \mu \mathrm{M}$ to the incubation media did not alter the secretion rates of GH and PRL in three different adenoma cells of acromegaly and in one experiment conducted using nonadenomatous human pituitary cells. When coincubated with dopamine, opioid peptides did not affect the suppressive effect of dopamine on GH and PRL secretion from adenoma cells of acromegaly in three experiments and from nonadenomatous pituitary cells in one experiment.

\section{DISCUSSION}

The foregoing results have clearly shown that dopaminergic agonists such as dopamine and bromocriptine act on pituitary adenoma cells from acromegalic patients to inhibit $\mathrm{GH}$ secretion, which is consistent with our earlier observation that bromo- criptine directly suppressed GH and PRL release by perfused pituitary adenoma tissues of acromegaly (13). The minimum effective concentration of dopamine required for a significant inhibition of $\mathrm{GH}$ secretion was in the range of 0.01 to $0.1 \mu \mathrm{M}$, which indicates that pituitary adenoma cells of acromegaly are sensitive to dopaminergic agonists. This action of dopamine may be occasioned via a dopaminergic mechanism, since the addition of a nonselective dopaminergic antagonist, haloperidol, blocked the dopamine effect. It is now apparent that dopamine receptor exists in more than one subtype (31), although an argument is raised against this view by some of the workers (32). A selective $D_{2}$ receptor antagonist, metoclopramide or sulpiride, was shown in the present study to reverse the inhibitory effect of dopamine on GH secretion from pituitary adenoma cells of acromegaly, while a $D_{1}$ receptor blockade was ineffective. It was concluded that dopaminergic agonists may suppress $\mathrm{GH}$ secretion by acting at $D_{2}$ receptor on pituitary adenoma cell membranes of acromegaly.

Similarly, dopamine exerted its direct action to reduce hormone release in a dose-dependent manner in nonadenomatous pituitary somatotrophs. This inhibitory effect of dopamine was again blocked by $D_{2}$ receptor blockade. The result suggests that no qualitative difference exists in $\mathrm{GH}$ response to dopamine between nonadenomatous human pituitary somatotrophs and 
adenoma cells of acromegaly. Of interest is the observation that infusion of dopamine to man abolishes the $\mathrm{GH}$ response to hypoglycemia (33). This fact might be explained by the direct inhibitory effect of dopamine on pituitary somatotrophs to overcome the stimulation of $\mathrm{GH}$ release mediated via central nervous system. Very recently, the in vitro inhibition of $\mathrm{GH}$ secretion from human pituitary cells with higher concentrations of dopamine (1-10 $\mu \mathrm{M})$ or bromocriptine has been reported by other investigators $(16,17,34)$. Whether the observed effect was ascribed to a specific dopaminergic action, however, is unclear, because the reversal of the effect by dopaminergic blockade was not established in their studies. It should be noted in this regard that the minimum effective concentration of dopamine to suppress $\mathrm{GH}$ secretion from nonadenomatous somatotrophs was $0.1 \mu \mathrm{M}$. In view of this rather high concentration, the physiological significance of the dopamine-induced inhibition of $\mathrm{GH}$ release remains obscure.

Dopaminergic agonists showed a suppressive effect on PRL secretion from nonadenomatous human lactotrophs as well as from pituitary adenoma cells of acromegaly in culture. That this is secondary to the degradation of PRL in the incubation media by dopaminergic agonists recently observed by Dannies and Rudnick (35) seems unlikely, since PRL release was restored by dopaminergic blockade. The minimum effective dose of dopamine required for a significant inhibition of PRL release was smaller than that for $\mathrm{GH}$ release. Dopamine at a concentration of $0.01 \mu \mathrm{M}$ or less effectively inhibits the secretion of PRL, which is close to the dopamine concentration in hypophysial stalk blood of the rat (36-39) and the monkey (40). Recently, Denef et al. (41) reported that dopamine at concentrations of 1-100 pM enhanced PRL release from perfused rat pituitary cells. Such a phenomenon, however, was not observed in nonadenomatous human lactotrophs in culture, suggesting that the dual action of dopamine in the regulation of PRL secretion does not operate in man.

The direct effect of L-dopa on GH and PRL release by pituitary adenoma cells of acromegaly was not clear. The result may indicate that pituitary adenoma cells of acromegaly have little, if any, L-dopa decarboxylase activity. Peillon et al. (15) reported that L-dopa significantly lowered both GH and PRL secretion from human pituitary adenomas of acromegaly. The reason for discrepancy between their study and ours remains unclear. That pituitary adenomas were exposed to higher concentrations (1-100 $\mu \mathrm{M})$ of L-dopa for a longer period in their study may be one of the possible explanations.

Norepinephrine inhibited PRL secretion from both adenoma cells of acromegaly and nonadenomatous lactotrophs. This effect of norepinephrine was blocked by $D_{2}$ receptor blockade, however, alpha adrenergic blockade with phentolamine was ineffective. The result suggests that norepinephrine induced the inhibitory effect on PRL secretion through its intrinsic dopaminergic activity. In fact, L-norepinephrine has been shown in bovine anterior pituitary cell membranes to compete for $\left[{ }^{3} \mathrm{H}\right]$ dihydroergocriptine binding with a potency of $15 \%$ relative to dopamine (42). The direct effect of norepinephrine on $\mathrm{GH}$

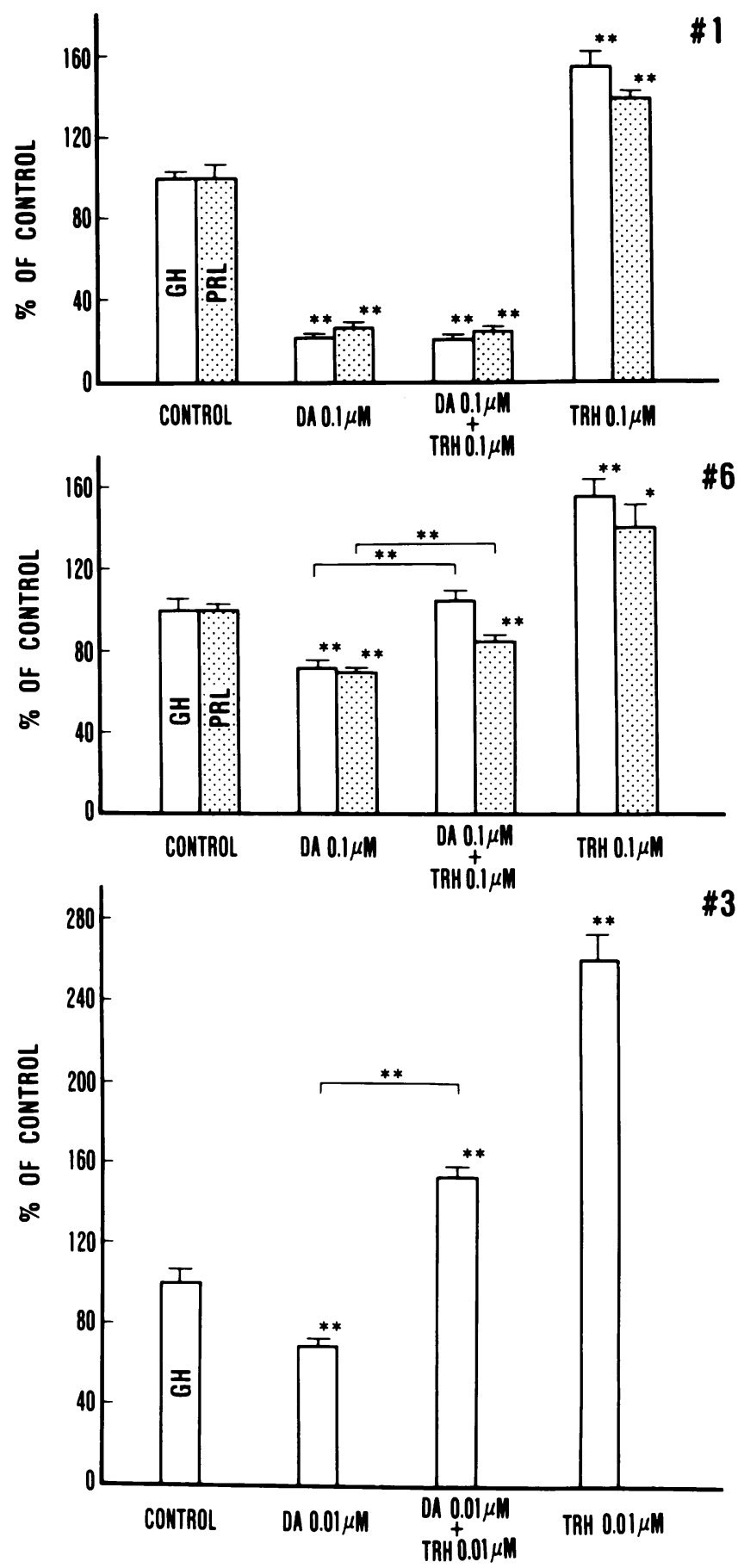

Figure 9. Effect of dopamine (DA) and TRH alone or in combination on GH and PRL secretion by cultured adenoma cells obtained from patients with acromegaly (patients 1,3 , and 6). Open histograms represent GH and shaded histograms PRL. A minimum of four replicates was used for each variable. Results are expressed as the percentage of change in secretion relative to a preincubation in medium alone. For comparison, the mean values in the control incubation were designated as $100 \%$. Results are the mean \pm SEM. ${ }^{*} P<0.05 ;{ }^{* *} P<0.01$. 

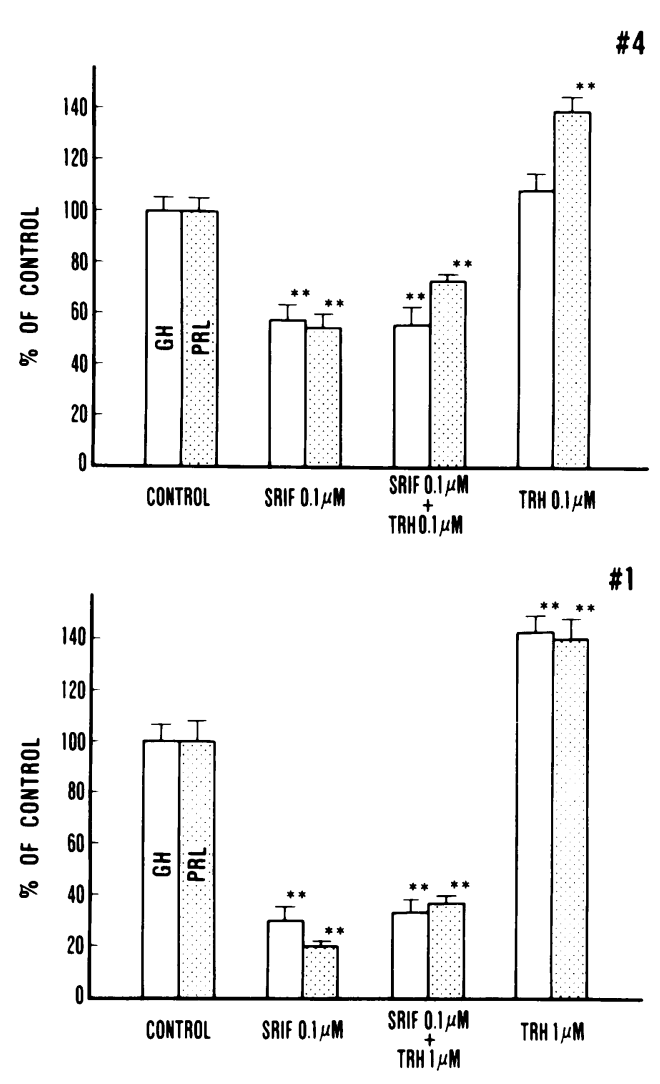
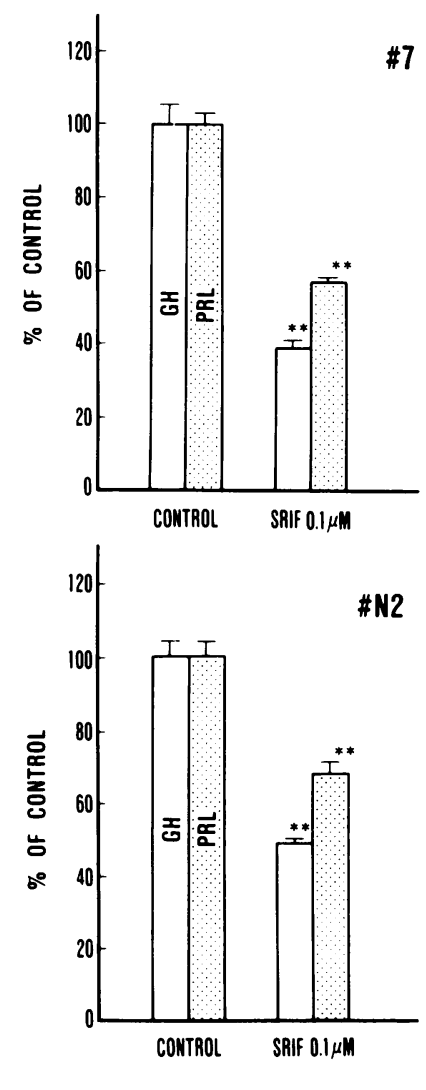

Figure 10. Effect of somatostatin (SRIF) and TRH alone or in combination on GH and PRL secretion by cultured adenoma cells obtained from patients with acromegaly (patients 1,4 , and 7) and by nonadenomatous human pituitary cells obtained from a patient with Cushing's disease (patient N2) at the time of hypophysectomy. Open histograms represent $\mathrm{GH}$ and shaded histograms PRL. A minimum of four replicates was used for each variable. Results are expressed as the percentage of change in secretion relative to a preincubation in medium alone. For comparison, the mean values in the control incubation were designated as $100 \%$. Results are the mean \pm SEM. ${ }^{*} P<0.05 ;{ }^{* *} P<0.01$. secretion, on the other hand, was not consistently observed, although norepinephrine $(1 \mu \mathrm{M})$ significantly inhibited GH release in some experiments, which was blocked by the $D_{2}$ receptor blockade. It was concluded that the action of catecholamines on GH and PRL secretion from adenoma cells of acromegaly and nonadenomatous pituitary cells is mainly mediated through a dopaminergic mechanism.

In adenoma cells of acromegaly, TRH stimulated both GH and PRL secretion, while it did only the latter in nonadenomatous pituitary cells in one experiment. This is consistent with the in vivo observation that TRH does not exhibit any effect on GH secretion in healthy subjects. Somatostatin, on the other hand, inhibited GH and PRL secretion in adenoma cells of acromegaly as well as in nonadenomatous pituitary cells in culture. Although it is now well established that somatostatin suppresses the circulating levels of GH in normal men and in patients with acromegaly (43-45), its effect on PRL is controversial. Somatostatin may reduce plasma PRL levels in some, but not all, acromegalic patients, whereas plasma PRL concentrations are generally unaffected by somatostatin in healthy individuals. The discrepancy between in vivo and in vitro responses to somatostatin in normal subjects may be explained in part by the fact that nonadenomatous lactotrophs are less sensitive to somatostatin than somatotrophs as demonstrated in the present study and in part by the assumption that somatostatin may be more rapidly degraded in the circulation than in the incubation media.

When dopamine and TRH were coincubated, the response of GH secretion from adenoma cells of acromegaly was variable. In contrast, the stimulatory effect of TRH was unequivocally blocked by somatostatin even when a 10-fold higher concentration of TRH was used. These results, along with a difference in the sensitivity of GH and PRL cells to two substances alluded to above, suggest that there may exist a difference in the mode of the inhibitory action on hormone release between dopamine and somatostatin.

Although it has been recently shown that opioid peptides elevate the circulating levels of GH and PRL in man and in experimental animals (46-50), there is a controversy regarding the mechanism of action of opioid peptides to stimulate hormone release. In rat pituitaries, opioid peptides were found to counteract the inhibitory effect of dopamine on PRL secretion in vitro (51). However, opioid peptides alone or in combination with dopamine were completely inert in stimulation of PRL secretion from both adenomatous and nonadenomatous lactotrophs in the present study, which may agree with the ob- 
servation that the inhibition of PRL secretion induced by dopamine was not overcome by opioid peptides in perfused rat pituitaries (52). The result may support the view that in man the site of action of opioid peptides on GH and PRL secretion may be the hypothalamus or higher central nervous system.

\section{Acknowledgments}

The authors are indebted to Professor F. Takaku for his support, to Dr. T. Fukushima, to Dr. T. Hori, and to Dr. A. Teramoto, Department of Neurosurgery, for providing us with pituitary tissues obtained at surgery. They are also grateful to Dr. H. Demura, Tokyo Womens' Medical College, for providing us with an anti-hGH serum, and to the National Institute of Arthritis, Metabolism, and Digestive Diseases, and the National Pituitary Agency, U. S. Public Health Service for the generous gift of GH and PRL radioimmunoassay kits. YM-09151-2 was kindly supplied by Dr. Usui, Yamanouchi Pharmaceutical Co., Tokyo, Japan, and bromocriptine mesylate by Sandoz Ltd., Basel, Switzerland.

This work was supported in part by a grant-in-aid for scientific research from the Ministry of Education, Japan.

\section{References}

1. Boyd, A. E., III, H. E. Lebovitz, and J. B. Pfeiffer. 1970. Stimulation of human growth hormone secretion by L-dopa. N. Engl. J. Med. 238:1425-1429.

2. Lal, S., C. E. de la Vega, T. L. Sourkes, and H. G. Friesen. 1972. Effect of apomorphine on human growth hormone secretion. Lancet. II:661.

3. Cammanni, F., F. Massara, L. Belforte, and G. M. Molinatti. 1975. Changes in plasma growth hormone levels in normal and acromegalic subjects following administration of 2-bromo- $\alpha$-ergocriptine. $J$. Clin. Endocrinol. Metab. 40:363-366.

4. Leebaw, W. F., L. A. Lee, and P. D. Woolf. 1978. Dopamine affects basal and augmented pituitary hormone secretion. J. Clin. Endocrinol. Metab. 47:480-487.

5. Liuzzi, A., P. G. Chiodini, L. Botalla, G. Cremascoli, and F. Silverstrini. 1972. Inhibitory effect of L-dopa on GH release in acromegalic patients. J. Clin. Endocrinol. Metab. 35:941-943.

6. Liuzzi, A., P. G. Chiodini, L. Botalla, G. Cremascoli, E. E. Müller, and F. Silvestrini. 1974. Decreased plasma growth hormone (GH) levels in acromegalics following CB154 (2-Br- $\alpha$-ergocriptine) administration. J. Clin. Endocrinol. Metab. 38:910-912.

7. Ishibashi, M., T. Yamaji, and K. Kosaka. 1977. Effect of bromoergocriptine on TRH-induced growth hormone and prolactin release in acromegalic patients. J. Clin. Endocrinol. Metab. 45:275-279.

8. Ishibashi, M., T. Yamaji, and K. Kosaka. 1978. Induction of growth hormone and prolactin secretion by luteinizing hormone-releasing hormone and its blockade by bromoergocriptine in acromegalic patients. J. Clin. Endocrinol. Metab. 47:418-421.

9. Thorner, M. O., A. Chait, M. Aitken, G. Benker, S. R. Bloom, C. H. Mortimer, P. Sanders, A. Stuart Mason, and G. M. Besser. 1975. Bromocriptine treatment of acromegaly. Br. Med. J. 1:299-303.

10. Sachdev, Y., A. Gomez-Pan, W. M. G. Turnbridge, A. Duns, D. R. Weightman, R. Hall, and S. K. Goolamali. 1975. Bromocriptine therapy in acromegaly. Lancet. II:1164-1168.

11. Wass, J. A. H., M. O. Thorner, D. V. Morris, L. H. Rees,
A. S. Mason, A. E. Jones, and G. M. Besser. 1977. Long-term treatment of acromegaly with bromocriptine. Br. Med. J. 1:875-878.

12. Yamaji, T., M. Ishibashi, K. Kosada, T. Fukushima, T. Hori, S. Manaka, and K. Sano. 1981. Pituitary apoplexy in acromegaly during bromocriptine therapy. Acta Endocrinol. 98:171-177.

13. Ishibashi, M., and T. Yamaji. 1978. Effect of thyrotropin-releasing hormone and bromoergocriptine on growth hormone and prolactin secretion in perfused pituitary adenoma tissues of acromegaly. J. Clin. Endocrinol. Metab. 47:1251-1256.

14. Adams, E. F., I. E. Brajkovich, and K. Mashiter. 1979. Hormone secretion by dispersed cell cultures of human pituitary adenomas: effect of theophylline, thyrotropin-releasing hormone, somatostatin, and 2bromo- $\alpha$-ergocryptine. J. Clin. Endocrinol. Metab. 49:120-126.

15. Peillon, F., F. Cesselin, D. Bression, N. Zygelman, A. M. Brandi, A. Nousbaum, and A. Mauborgne. 1979. In vitro effect of dopamine and L-dopa on prolactin and growth hormone release from human pituitary adenomas. J. Clin. Endocrinol. Metab. 49:737-741.

16. Tallo, D., and W. B. Malarkey. 1981. Adrenergic and dopaminergic modulation of growth hormone and prolactin secretion in normal and tumor-bearing human pituitaries in monolayer culture. $J$. Clin. Endocrinol. Metab. 53:1278-1284.

17. Lawton, N. F., A. J. Evans, and R. O. Weller. 1981. Depaminergic inhibition of growth hormone and prolactin release during continuous in vitro perifusion of normal and adenomatous human pituitary. $J$. Neurol. Sci. 49:229-239.

18. Bression, D., A. M. Brandi, A. Nousbaum, M. Le Dafniet, J. Racadot, and F. Peillon. 1982. Evidence of dopamine receptors in human growth hormone $(\mathrm{GH})$-secreting adenomas with concomitant study of dopamine inhibition of GH secretion in a perfusion system. J. Clin. Endocrinol. Metab. 55:589-593.

19. Irie, M., and T. Tsushima. 1972. Increase of serum growth hormone concentration following thyrotropin-releasing hormone injection in patients with acromegaly and gigantism. J. Clin. Endocrinol. Metab. 35:97-99.

20. Shalch, D. S., D. Gonzales-Barcena, A. J. Kastin, A. V. Shally, and L. A. Lee. 1972. Abnormalities in the release of TSH in response to thyrotropin-releasing hormone (TRH) in patients with disorders of the pituitary, hypothalamus, and basal ganglia. J. Clin. Endocrinol. Metab. 35:609-615.

21. Cryer, P. E., and W. H. Daughaday. 1974. Adrenergic modulation of growth hormone secretion in acromegaly: suppression during phentolamine and phentolamine-isoproterenol administration. J. Clin. Endocrinol. Metab. 39:658-663.

22. Cryer, P. E., and W. H. Daughaday. 1977. Adrenergic modulation of growth hormone secretion in acromegaly: alpha and beta adrenergic blockade produce qualitatively normal responses but no effect on Ldopa suppression. J. Clin. Endocrinol. Metab. 44:977-979.

23. Feldman, J. M., J. W. Plonk, and C. H. Bivens. 1976. Inhibitory effect of serotonin antagonists on growth hormone release in acromegalic patients. Clin. Endocrinol. 5:71-78.

24. Chiodini, P. G., A. Liuzzi, E. E. Müller, L. Botalla, G. Cremascoli, G. Oppizzi, G. Verde, and F. Silvestrini. 1976. Inhibitory effect of an ergoline derivative, methergoline, on growth hormone and prolactin levels in acromegalic patients. J. Clin. Endocrinol. Metab. 43:356-363.

25. Ishibashi, M., and T. Yamaji. 1981. Direct effects of thyrotropinreleasing hormone, cyproheptadine, and dopamine on adrenocorticotropin secretion from human corticotroph adenoma cells in vitro. $J$. Clin. Invest. 68:1018-1027.

26. Mains, R. E., and B. A. Eipper. 1976. Biosynthesis of adreno- 
corticotropic hormone in mouse pituitary tumor cells. J. Biol. Chem. 251:4115-4120.

27. Yamaji, T., M. Ishibashi, S. Katayama, A. Itabashi, N. Ohsawa, Y. Kondo, Y. Mizumoto, and K. Kosaka. 1981. Neurophysin biosynthesis in vitro in oat cell carcinoma of the lung with ectopic vasopressin production. J. Clin. Invest. 68:1441-1449.

28. Lawrence, A., A. Frohman, L. Burek, and M. E. Stachura. 1972. Characterization of growth hormone of different molecular weights in rat, dog, and human pituitaries. Endocrinology. 91:262-269.

29. Nishikori, K., O. Noshiro, K. Sano, and H. Maeno. 1980. Characterization, solubilization, and separation of two distinct dopamine receptors in canine caudate nucleus. J. Biol. Chem. 255:10909-10915.

30. Yamaji, T., K. Shimamoto, M. Ishibashi, K. Kosaka, and H. Orimo. 1976. Effect of age and sex on circulating and pituitary prolactin levels in humans. Acta Endocrinol. 83:711-719.

31. Kebabian, J. W., and D. B. Calne. 1979. Multiple receptors for dopamine. Nature (Lond.). 277:93-96.

32. Cronin, M. J. 1982. The role and direct measurement of the dopamine receptor(s) in the anterior pituitary. In Neuroendocrine Perspectives. E. E. Müller and R. M. MacLeod, editors. Elsevier NorthHolland, Inc., New York. 1:169-210.

33. Woolf, P. D., R. Lantigua, and L. A. Lee. 1979. Dopamine inhibition of stimulated growth hormone secretion: evidence for dopaminergic modulation of insulin- and L-dopa-induced growth hormone secretion in man. J. Clin. Endocrinol. Metab. 49:326-330.

34. Adams, E. F., I. E. Brajkovich, and K. Mashiter. 1981. Growth hormone and prolactin secretion by dispersed cell cultures of a normal human pituitary: effects of thyrotrophin-releasing hormone, theophylline, somatostatin, and 2-bromo- $\alpha$-ergocryptine. Acta Endocrinol. 98:345351.

35. Dannies, P. S., and M. S. Rudnick. 1980. 2-Bromo- $\alpha$-ergocriptine causes degradation of prolactin in primary cultures of rat pituitary cells after chronic treatment. J. Biol. Chem. 255:2776-2781.

36. Ben-Jonathan, N., C. Oliver, H. J. Weiner, R. S. Mical, and J. C. Porter. 1977. Dopamine in hypophysial portal plasma of the rat during the estrous cycle and throughout pregnancy. Endocrinology. 100:425-458.

37. Shaar, C. J., and J. A. Clemens. 1974. The role of catecholamines in the release of anterior pituitary prolactin in vitro. Endocrinology. 95:1202-1212.

38. Gibbs, D. M., and J. D. Neill. 1978. Dopamine levels in hypophysial stalk blood in the rat are sufficient to inhibit prolactin secretion in vivo. Endocrinology. 102:1895-1900.

39. Neill, J. D. 1980. Neuroendocrine regulation of prolactin se- cretion. In Frontiers in Neuroendocrinology. L. Martini and W. F. Ganong, editors. Raven Press, New York. 6:129-155.

40. Neill, J. D., L. S. Frawley, P. M. Plotsky, and G. T. Tindall. 1981. Dopamine in hypophysial stalk blood of the rhesus monkey and its role in regulating prolactin secretion. Endocrinology. 108:489-494.

41. Denef, C., D. Monet, and R. Dewals. 1980. Dopaminergic stimulation of prolactin release. Nature (Lond.). 285:243-285.

42. Caron, M. G., M. Beaulieu, V. Raymond, B. Gagné, J. Drouin, R. J. Lefkowitz, and F. Labrie. 1978. Dopaminergic receptors in the anterior pituitary gland: correlation of $\left[{ }^{3} \mathrm{H}\right]$ dihydroergocryptine binding with the dopaminergic control of prolactin release. J. Biol. Chem. 253:2244-2253.

43. Hall, R., G. M. Besser, A. V. Schally, D. H. Coy, D. Evered, D. J. Goldie, A. J. Kastin, A. S. McNeilly, C. H. Mortimer, C. Phenekos, W. M. G. Tunbridge, and D. Weightman. 1973. Action of growthhormone-release inhibitory hormone in healthy men and in acromegaly. Lancet. II:581-584.

44. Siler, T. M., G. VandenBerg, S. S. C. Yen, P. Brazeau, W. Vale, and R. Guillemin. 1973. Inhibition of growth hormone release in humans by somatostatin. J. Clin. Endocrinol. Metab. 37:632-634.

45. Yen, S. S. C., T. M. Siler, and G. W. DeVane. 1974. Effect of somatostatin in patients with acromegaly: suppression of growth hormone, prolactin, insulin, and glucose levels. $N$. Engl. J. Med. 290:935938.

46. Dupont, A., L. Cusan, M. Garon, F. Labrie, and C. H. Li. 1977. $\beta$-Endorphin: stimulation of growth hormone release in vivo. Proc. Natl. Acad. Sci. USA. 74:358-359.

47. River, C., W. Vale, N. Ling, M. Brown, and R. Guillemin. 1977. Stimulation in vivo of the secretion of prolactin and growth hormone by $\beta$-endorphin. Endocrinology. 100:238-241.

48. Shaar, C. J., R. C. A. Frederickson, N. B. Dininger, and L. Jackson. 1977. Enkephalin analogues and naloxone modulate the release of growth hormone and prolactin-evidence for regulation by an endogenous opioid peptide in brain. Life Sci. 21:853-860.

49. Tolis, G., R. Dent, and H. Guyda. 1978. Opiates, prolactin, and dopamine receptor. J. Clin. Endocrinol. Metab. 47:200-203.

50. von Graffenried, B., E. del Pozo, J. Roubicek, E. Krebs, W. Pöldinger, P. Burmeister, and L. Kerp. 1978. Effects of the synthetic enkephalin analogue FK 33-824 in man. Nature (Lond.). 272:729-730.

51. Enjalbert, A., M. Ruberg, S. Arancibia, M. Priam, and C. Kordon. 1979. Endogenous opiates block dopamine inhibition of prolactin secretion in vitro. Nature (Lond.). 280:595-597.

52. Grossman, A., and V. Clement-Jones. 1983. Opiate receptors. J. Clin. Endocrinol. Metab. 12:31-56. 